\title{
A CORRELATIVE STUDY BETWEEN SERUM URIC ACID AND hS-CRP IN PATIENTS WITH ISCHAEMIC HEART DISEASE
}

Munty Bhattacharya, Happy Chutia, R. K. Goswami.
1. M \& HO in Maternity \& Child Health Care Centre. Department of Biochemistry, Dhirenpara, Guwahati, Assam.
2. Senior Resident Doctor, Department of Biochemistry, NEIGRIHMS, Shillong Meghalaya.
3. Professor \& Head, Department of Biochemistry, Assam Medical College \& Hospital, Dibrugarh, Assam.

\section{CORRESPONDING AUTHOR}

Dr. Happy Chutia, C/O Dr Akash Handique, Quarter No Type B 5A, NEIGRIHMS

Shillong, Meghalaya, India, PIN: 793018

E-mail: happy.chutia@gmail.com,

Ph: 00919435031695.

ABSTRACT: INTRODUCTION: Uric acid (UA) contributes to the development of human vascular disease and atherosclerosis through a pro-inflammatory pathway. Highly-sensitive Creactive protein (hs-CRP) also has emerged as the most exquisitely sensitive systemic marker of inflammation and a powerful predictive marker of future cardiovascular risk. In this study we estimated the levels of serum uric acid and hs- CRP in patients with ischaemic heart disease and association between them. METHODS: Study was carried out among fifty (50) newly diagnosed patients of ischaemic heart disease and fifty (50) age and sex matched healthy controls. Serum uric acid, hs-CRP, random glucose, urea, creatinine and cardiac troponin-I were measured.

RESULTS: The mean serum uric acid level in the control group was $4.66 \pm 0.97 \mathrm{mg} / \mathrm{dl}$ and in case group was $6.86 \pm 0.90 \mathrm{mg} / \mathrm{dl}$. Mean hs-CRP level in control group was $0.19 \pm 0.09 \mathrm{mg} / \mathrm{dl}$, in case group was $5.14 \pm 2.11 \mathrm{mg} / \mathrm{dl}$. There was a positive association between UA and hs-CRP but the correlation was statistically not significant ( $p>0.05$ ). CONCLUSION: Our study indicated that there was a statistically significant association between ischaemic heart disease patients and elevated serum UA and serum hs-CRP and hence a strong role in the pathophysiology of ischaemic heart disease.

KEY WORDS: Ischaemic heart disease, hs-CRP, uric acid.

INTRODUCTION: With urbanization in the developing world, the prevalence of risk factors for Ischemic heart disease (IHD) is increasing rapidly in these regions such that a majority of the global burden of IHD is now occurring in low-income and middle-income countries. Population subgroups that appear to be particularly affected are men in South Asian countries, especially India (1).

The most common cause of IHD is atherosclerosis disease of an epicardial coronary artery (or arteries) sufficient to cause a regional reduction in myocardial blood flow and inadequate perfusion of the myocardium supplied by the involved coronary artery (1). It leads to increased uric acid generation (from adenosine breakdown) and reduced excretion (due to lactate competing with urate transporter in the proximal tubule of kidney) (2).

Hyperuricaemia is most commonly defined by plasma uric acid concentration greater than $7.0 \mathrm{mg} / \mathrm{dl}$ in men or greater than $6.0 \mathrm{mg} / \mathrm{dl}$ in women (3). The association of hyperuricaemia with cardiovascular disease remains controversial. There has been no test of 
hypothesis that a reduction in serum uric acid would prevent cardiovascular disease. Serum uric acid probably reflects and integrates different risk factors and their possible interaction. (4)

C-reactive protein is an acute phase reactant initially developed to, evaluate patients with infection. It was originally discovered by Tillet and Francis in 1930 as a substance in the serum of patients with acute inflammation that reacted with the C-polysaccharide of Pneumococcus. A high-sensitivity CRP (hs-CRP) test measures low levels of CRP (5).CRP has been shown to actively participate in both atheromatous lesions formation and plaque disruption $(6,7)$. CRP increases the expression of endothelial adhesion molecules and monocyte chemoattractant protein-1 (MCP-1), facilitates native LDL uptake into macrophages, promotes monocyte activation and a procoagulant effect by inducing monocytes to synthesize tissue factor $(8,9)$. CRP can also activate the classic pathway of complement activation and has been demonstrated to co-localize with terminal complement complexes in established coronary plaques (10).

Many recent studies have proved higher serum level of uric acid and high sensitivity Creactive protein (hs-CRP) associated with ischemic heart disease. But very few comprehensive studies have yet been done to determine the correlation between serum uric acid level and hsCRP level in ischemic heart disease. This study was therefore undertaken to determine the concentrations of serum uric acid and serum hs-CRP in IHD patients and to evaluate the association and correlation between them if there is any.

MATERIALS AND METHODS: This case-control study was carried out among fifty (50) newly diagnosed patients of ischaemic heart disease $\geq 20$ years of age, admitted in Cardiology department of Assam Medical College and Hospital, Dibrugarh. Patients with inflammatory diseases like gout, rheumatoid arthritis, inflammatory bowel disease, renal disease, hypothyroid, diabetes, stroke, malignancy, bacterial infections were excluded from the study. Fifty age and sex matched healthy individuals were taken as control .Blood samples were collected from the subjects and estimation of serum uric acid, hs-CRP, random glucose, urea, creatinine and cardiac troponin-I were measured. Estimation of serum uric acid, random glucose, urea, and creatinine were done in Dimension RxL Max autoanalyzer. Serum UA was estimated by PAP / uricase method. Normal Reference Values with this method were 3.4-7.0 $\mathrm{mg} / \mathrm{dl}$ for male and 2.5-6.0 mg/dl for female (11).Serum hs-CRP, was analysed in the Dimension RxL Max autoanalyzer using Particle Enhanced Turbidimetric Immunoassay (PETIA) Technique. Normal Reference Value for hs-CRP according to this method was $0.0-0.5 \mathrm{mg} / \mathrm{dl}$ (12). Qualitative estimation of cardiac troponin-I was done by using membrane-based immunoassay to confirm the diagnosis of ischaemic heart disease with ready to use Trop I Scan Test Device manufactured by Zydus Pathline.

A database was constructed on Microsoft Excel 2007, and statistical analysis was done using statistical package for social sciences (SPSS) Windows version 14. Student's t-test, and Pearson correlation were done to analyze the data.

RESULTS: The mean levels of serum glucose, urea and creatinine were within reference range in both cases and controls.

The mean serum uric acid level in the control group was $4.66 \pm 0.97 \mathrm{mg} / \mathrm{dl}$ (in males : $4.98 \pm 0.79 \mathrm{mg} / \mathrm{dl}$ and in females : $3.53 \pm 0.63 \mathrm{mg} / \mathrm{dl}$ ) and in case group was $6.86 \pm 0.90 \mathrm{mg} / \mathrm{dl}($ in males : $7.07 \pm 0.86 \mathrm{mg} / \mathrm{dl}$ and in females, $6.12 \pm 0.58 \mathrm{mg} / \mathrm{dl}$ ). A highly significant increase in serum uric acid level was found in IHD subjects as compared to that in normal healthy 
individuals with $\mathrm{p}<0.001$. Higher values of serum uric acid level was found in the age groups $60-<70$ years and $40-<50$ years in the control group. The higher values of serum uric acid in the cases were in the age group of $60-<70$ yrs and $\geq 80$ years. In both the study groups, the mean value of serum uric acid had no relation with age (Table 1 ).

The mean hs-CRP level in control group was $0.19 \pm 0.09 \mathrm{mg} / \mathrm{dl}($ in males: $0.18 \pm 0.08$ $\mathrm{mg} / \mathrm{dl}$ and in females : $0.25 \pm 0.07 \mathrm{mg} / \mathrm{dl}$ ) and in case group was $5.14 \pm 2.11 \mathrm{mg} / \mathrm{dl}(\mathrm{in}$ males:5.06 $\pm 2.17 \mathrm{mg} / \mathrm{dl}$ and in females : $5.44 \pm 1.98 \mathrm{mg} / \mathrm{dl}$ ). A highly significant increase in serum hs-CRP level was found in IHD subjects as compared to that in normal healthy individuals ( $p<0.001)$. Mean value of serum hs-CRP level in controls increased with the increase in age. The highest value was in the age group of $\geq 80$ years. In the cases, the mean value of hs-CRP level was high in the age groups of $60-<70$ years and $\geq 80$ years (Table2).

The correlation coefficient ' $r$ ' between serum uric acid and serum hs-CRP was found to be 0.124 with $p$-value $>0.05$ which means that statistically, the correlation is not significant.

DISCUSSION: In the present study, the minimum age of presentation of IHD was found to be thirty-eight (38) years and the maximum was of 85 years. The age-wise distribution revealed the highest percentage of cases in the age group $60-<70$ years (26\%) followed by $24 \%$ in $50-$ $<60$ years and $20 \%$ in $40-<50$ years. Also, there were $2 \%$ cases in the age group of $<40$ years. Similar findings were also observed by Krisnaswami et al (1970) and Џhatakia KU et al (1967) $(13,14)$. Yusuf et al $(2004)$ reported that mean age of presentation on with new MI was 52 years in South Indians, 9.7\% of these cases were younger than 40 years of age (15).

In the present study, there were 39 (78\%) males and $11(12 \%)$ females with male to female ratio of 3.5:1. Almost similar finding was found by Singh et al (14). They reported a ratio of 3.8:1 between males and females. The lower incidence of IHD in women, especially in premenopausal age, was probably due to high levels of oestrogens and high density lipoprotein, both of which have anti-atherogenic influence.

In our study, the mean serum uric acid level was found to be significantly higher than in ischaemic heart disease patients $(6.86 \pm 0.90 \mathrm{mg} / \mathrm{dl})$ that in the control group $(4.66 \pm 0.97$ $\mathrm{mg} / \mathrm{dl}$ ). Similar results were also found by Morris London et al (1967) and M. Torun et al (1998) $(16,17)$. The role of uric acid as risk factor for myocardial infarction is controversial. The Rotterdam Study concluded that uric acid is a strong risk factor for myocardial infarction and stroke (18). Hong Evy Lim et al (2010) has also found that serum uric acid was higher in patients with coronary artery disease as compared to normal healthy individuals (19).

In the present study, the mean serum hs-CRP level in ischaemic heart disease patients $(5.14 \pm 2.11 \mathrm{mg} / \mathrm{dl})$ was found to be significantly higher than in control group $(0.19 \pm 0.09$ $\mathrm{mg} / \mathrm{dl}$ ). Similar results were found by Arroyo et al (2004), N. Yilmaz et al (2007) and Suman B Sharma et al (2008) (20,21,22). Significantly higher hs-CRP levels were found in angiographically proven CAD patients with acute coronary syndrome as compared to patients with normal coronary angiography; and the levels of hs-CRP correlated well with the angiographic severity of the CAD (23). Also mean hs-CRP level in females ( $5.44 \pm 1.98 \mathrm{mg} / \mathrm{dl}$ ) is slightly higher as compared with males $(5.06 \pm 2.17 \mathrm{mg} / \mathrm{dl})$ with IHD. Ross Arena et al (2006) also found a significantly higher hs-CRP level in females as compared with males (24).

These findings may indicate that serum uric acid and serum hs-CRP may have some role in the pathophysiology of ischaemic heart disease. The present study is consistent with earlier studies wherein it was concluded that higher levels of serum uric acid and hs-CRP were associated with poor prognosis of the ischaemic heart disease patients.

Journal of Evolution of Medical and Dental Sciences/Volume1/Issue5/November-2012Page-648 
In the present study, serum uric acid and serum hs-CRP were found to be positively associated $(r=0.124)$ but the correlation was not found to be significant. This finding is consistent with the study of Zhang Y H et al in 2009 (25). However a statistically significant correlation was found between serum CRP and serum UA in studies done by N. Yilmaz et al (2007) and Christa Meisinger et al $(21,26)$.

So, for a definitive conclusion regarding the usefulness of these two parameters as markers of cardiovascular risk factors and to know the mechanism by which uric acid and hsCRP play role in the pathophysiology of ischaemic heart disease, further studies comprising of large number of cases and longer duration of study are required.

\section{REFERENCES:}

1. Anthony S. Fauci, Eugene Braunwald, Dennis L. Kasper ,Stephen L. Hauser, Dan L. Longo , J. Larry Jameson ,et al; Harrison's Principle of Internal Medicine, $17^{\text {th }}$ Edition:1381-3.

2. Pluig JG, Ruilope LM. Uric acid as a cardiovascular risk factor in arterial hypertension. J Hypertens 1999 Jul;17(7):869-72

3. Carl A. Burtis, Edward R. Ashwood, David E. Bruns; Teitz's textbook of Clinical Chemistry and Molecular Diagnostics, $4^{\text {th }}$ Edition:803-5.

4. Culleton BF. Uric acid and cardiovascular disease a renal cardiac relationship; Curr. Opin. Nephrol. Hypertens May 2001:10(3):371-5.

5. Leo K. Niskanen, David E. Laaksonen, , Kristiina Nyyssönen, Georg Alfthan, HannaMaaria Lakka, et al. Uric acid level as a risk factor for cardiovascular and all-cause mortality in middle-aged man-A prospective cohort study; Arch Intern. Med. 2004 164(14):1546-1551

6. Tenzin Nyandak, Arun Gogna, Sandeep Bansal, Manorama Deb.High Sensitive CReactive Protein (hs-CRP) and its Correlation with Angiographic Severity of Coronary Artery Disease (CAD); JIACM 2007; 8(3): 217-21

7. Vincenzo Pasceri, James T. Willerson, Edward T. H. Yeh . Direct proinflammatory effect of CRP on human endothelial cells. Circulation 2000; 102: 2165-8.

8. Thomas P. Zwaka, Vinzenz Hombach, Jan Torzewski, . CRP-mediated LDL uptake by macrophages: implicates for atherosclerosis. Circulation 2001; 103: 1194-7.

9. SP Ballou, Gerard Lozanski. Induction of inflammatory cytokine release from cultured human monocytes to synthesize tissue factor. Blood 1993; 82: 513-20

10. Carolyn Mold Henry Gewurz, Terry W Du Clos. Regulation of complement activation by CRP. Immunopharmacology 1999; 42: 23-30

11. Town M.H.Gehm, S. Hammer, B. Ziegenhorn; J.Clin. Clin. Biochem(1985):23:591

12. Tie Q. Wei, Steve Kramer, Victor P. Chu, Dave,Hudson, Daniel Kilgore, Sue Salyer, et al. An improved automated immunoassay for C-reactive protein on the DimensionR clinical chemistry system; Journal of Automated Methods \& Management in Chemistry, Vol.22, No. 5 (September - October 2000): 125-131.

13. Krishnaswami V, Radhakrishnan T, Michael Johns B and Mathew A. Pattern of ischaemic heart disease: a clinical study; J Indian Med Asso 1970 ;55:153-57.

14. Jhatakia KU, Thakore PB, Vasavada PJ Observations on some facets of coronary artery disease.J Assoc Physicians India. 1967 Mar; 15(3):109-15.

15. Salim Yusuf, Steven Hawken, Stephanie Ôunpuu , Tony Dans , Alvaro Avezum, Fernando Lanas, Matthew McQueen et al. Effect of potentially modifiable risk factors 
associated with MI in 52 countries (The Interheart Study). Lancet 2004; 364: 937-52.

16. Morris London and Mary Hums. Distribution patterns of uric acid in CAD; Clinical Chemistry, 1967: Vol. 13:132-41.

17. M. Torun, S. Yardim, B. Simsek \& S. Burgaz: Serum uric acid levels in cardiovascular diseases; J Clinn Pharm Ther 1998; 23: 25-9

18. Bos MJ, Koudstall PJ, Hotman A, Wittman JC, Breteler MM. Uric acid is a risk factor for myocardial infarction and stroke: The Rotterdam Study. Stroke 2006 June; 37(6): 1503-7.

19. Hong Euy Lim, Seong Hwan Kim, Eung Ju Kim, Jin Won Kim. Clinical value of serum uric acid in patients with suspected coronary artery disease; The Korean Journal of Internal Medicine, March 2010: Vol. 25, No. 1:21-6.

20. Ramón Arroyo-Espliguero, Pablo Avanzas, Juan Cosín-Sales, Guillermo Aldama, Carmine Pizzi,Juan Carlos Kaski . CRP elevation and disease activity in patients with coronary artery disease; Eur Heart J 2004 Mar; 25(5): 401-8.

21. Yilmaz N, Ciçek HK, Celik A, Meram I, Kocabas R, Davutoglu V. Diagnostic value of homocysteine, C-reactive protein and bilirubin for coronary artery disease; Eastern Mediterranean Health Journal. May-June, 2007:Vol. 13(3). 522-35

22. Suman B. Sharma, Seema Garg, Abhinav Veerwal, Sridhar Dwivedi. hs-CRP and oxidative stress in young CAD patients: A Pilot Study; Indian Journal of Clinical Biochemistry 2008; 23(4): 334-36.

23. Tenzin Nyandak, Arun Gogna, Sandeep Bansal, Manorama Deb. hs-CRP and its correlation with Angiographic severity of coronary Artery Disease (CAD); Journal, Indian Academy of Clinical Medicine 2007; 8(3): 217-21.

24. Ross Arena, James A. Arrowood, Ding-Yu Fei, Shirley Helm, Kenneth A. Kraft. The Relationship between C-Reactive Protein and Other Cardiovascular Risk Factors in Men and Women; Journal of Cardiopulmonary Rehabilitation \& Prevention September/ October 2006, Volume 26 (5): 323-27.

25. Zhang YH, Lü R, Zhao XY, Kang LM, Yang YJ, Zhang J. Association of serum uric acid, plasma NT-proBNP, hs-C reactive protein and invasive hemodynamic parameters in patients with heart failure ; Zhonghua Xin Xue Guan Bing Za Zhi , Chinese journal of cardiovascular diseases :2009 Feb;37(2):126-9.

26. Christa Meisinger, Wolfgang Koenig, Jens Baumert and Angela Doring. The Uric Acid Levels Are Associated With All-Cause and Cardiovascular Disease Mortality Independent of Systemic Inflammation in Men From the General Population. MONICA/KORA Cohort Study; Arterioscler Thromb Vasc Biol 2008; 28:1186-92.

Table 1: Age-wise distribution of serum uric acid

\begin{tabular}{|l|l|l|l|l|}
\hline \multirow{2}{*}{$\begin{array}{l}\text { Age group } \\
\text { in years) }\end{array}$} & \multicolumn{4}{|l|}{ Serum uric acid $(\mathrm{mg} / \mathrm{dl})$} \\
\cline { 2 - 5 } & Range & \multicolumn{3}{l|}{ Mean \pm S.D. } \\
\cline { 2 - 5 } & Controls & Cases & Controls & Cases \\
\hline$<40$ & 4.3 & 6.2 & 4.3 & 6.2 \\
\hline $40-<50$ & $2.6-6.9$ & $5.0-8.2$ & $4.83 \pm 1.69$ & $6.63 \pm 0.97$ \\
\hline $50-<60$ & $3.2-5.9$ & $5.2-9.2$ & $4.73 \pm 0.77$ & $6.93 \pm 1.15$ \\
\hline $60-<70$ & $3.6-6.2$ & $5.5-8.5$ & $4.85 \pm 0.86$ & $7.02 \pm 1.00$ \\
\hline
\end{tabular}

Journal of Evolution of Medical and Dental Sciences/Volume1/Issue5/November-2012Page-650 


\begin{tabular}{|l|l|l|l|l|}
\hline $70-<80$ & $3.9-5.10$ & $5.9-7.8$ & $4.33 \pm 0.39$ & $6.78 \pm 0.63$ \\
\hline$\geq 80$ & $3.9-5.0$ & $6.8-7.3$ & $4.32 \pm 0.50$ & $7.00 \pm 0.19$ \\
\hline
\end{tabular}

Table2: Age-wise distribution of serum hs-CRP

\begin{tabular}{|l|l|l|l|l|}
\hline \multirow{2}{*}{$\begin{array}{l}\text { Age group } \\
\text { (in years) }\end{array}$} & \multicolumn{4}{|l|}{ Serum hs-CRP $(\mathrm{mg} / \mathrm{dl})$} \\
\cline { 2 - 5 } & Range & \multicolumn{3}{l|}{ Mean \pm S.D. } \\
\cline { 2 - 5 } & Controls & Cases & Controls & Cases \\
\hline$<40$ & 0.03 & 3.81 & 0.03 & 3.81 \\
\hline $40-<50$ & $0.05-0.25$ & $0.8-7.8$ & $0.15 \pm 0.07$ & $3.88 \pm 1.98$ \\
\hline $50-<60$ & $0.10-0.29$ & $1.3-9.2$ & $0.17 \pm 0.07$ & $4.30 \pm 2.68$ \\
\hline $60-<70$ & $0.10-0.32$ & $3.27-10.0$ & $0.19 \pm 0.08$ & $5.05 \pm 2.88$ \\
\hline $70-<80$ & $0.10-0.40$ & $3.72-8.50$ & $0.24 \pm 0.11$ & $4.99 \pm 2.90$ \\
\hline$\geq 80$ & $0.21-0.35$ & $3.9-8.20$ & $0.28 \pm 0.06$ & $5.25 \pm 2.28$ \\
\hline
\end{tabular}

Table-3: Statistical analysis for serum uric acid in the study groups

\begin{tabular}{|c|c|c|c|c|c|}
\hline Study group & $\begin{array}{l}\text { Number of } \\
\text { Observation }\end{array}$ & $\left\{\begin{array}{l}\text { Serum } \\
\text { Uric Aci } \\
(\text { Mean } \pm \text { S.D. }) \\
(\mathrm{mg} / \mathrm{dl})\end{array}\right.$ & $\begin{array}{l}\text { Degree } \\
\text { Freedom }\end{array}$ & of $\mid \begin{array}{l}\text { 't' } \\
\text { Value }\end{array}$ & $\mid \begin{array}{l}\text { 'p' } \\
\text { Value }\end{array}$ \\
\hline Controls & 50 & $4.66 \pm 0.97$ & \multirow{2}{*}{98} & \multirow{2}{*}{7.6} & \multirow{2}{*}{$<0.001$} \\
\hline Cases & 50 & $6.86 \pm 0.90$ & & & \\
\hline
\end{tabular}

Table-4: Statistical analysis for serum hs-CRP in the study groups

\begin{tabular}{|l|l|l|l|l|l|}
\hline Study group & $\begin{array}{l}\text { Number of } \\
\text { Observation }\end{array}$ & $\begin{array}{l}\text { Serum } \\
\text { hs-CRP (Mean } \pm \text { S.D.) } \\
\text { (mg/dl) }\end{array}$ & $\begin{array}{l}\text { Degree of ' } t \text { ' } \\
\text { Freedom } \\
\text { Value }\end{array}$ & ' $\mathrm{p}^{\prime}$ \\
Value
\end{tabular}

